\title{
National News / Nouvelles nationales
}

\section{Canadian Forestry Association Designates May 2 to 8 National Forest Week in 1999}

May 2 to 8 has been designated as National Forest Week for 1999 by the Canadian Forestry Association. People in communities across Canada are celebrating National Forest Week through tree planting, exhibits and school programs. Provincial governments, forest companies and schools across Canada are involved with National Forest Week activities.

"National Forest Week is a time for all Canadians to reflect on the good things we get from our forests," said Susan Gesner, President of the Canadian Forestry Association. National Forest Week has been celebrated since the 1920 s to remind us that forests are an essential part of all Canadians' lives. In addition to providing more than 800000 jobs, Canada's forests provide clean air, water wildlife habitat and recreational opportunities for millions of other Canadians.

This year's theme, Forest Fires: Handle with Care is particularly apt, because of the severe fire seasons of the last few years. "It is as important as ever to be very careful with fire in our forests," said
Ms. Gesner. Thousands of fires burned millions of hectares of forests across Canada last year.

Some provincial governments celebrate National Forest Week with alternate themes. For example, the British Columbia Ministry of Forests is celebrating National Forest Week in 1999 with the theme "The Magic of Biodiversity."

The Canadian Forestry Association, with the support of its partners and cooperators, produced and distributed 25000 National Forest Week Teacher's Guides to schools across Canada. The Canadian Forest Service, the Ontario Ministry of Natural Resources, Louisiana-Pacific Canada, Last Logos Inc., the Tree Canada Foundation, the Canadian Wood Council, Manitoba Natural Resources, Alberta Environmental Protection, Bombardier Aerospace and the Yukon Forestry Training Trust Fund all contributed to the program in 1999.

For more information contact Dan Cooligan, R.P.F., Manager, National Programs, Telephone: (613) 232-1815, www.canadianforestry.com.

\section{Yukon Protected Areas Strategy}

The Yukon has a new Protected Areas Strategy, tabled recently by Renewable Resources Minister Eric Fairclough in the legislature. The strategy acts out how Yukon people will identify and establish parks and other protected areas. In addition to the main document, Wild Spaces - Protected Places, the strategy includes seven technical papers and a two-year Work Plan. Together, they provide the framework for ensuring adequate protection of core areas in each of the Yukon's 23 distinct ecoregions.

"Besides protecting natural features, this strategy also identifies the processes for protecting special social, cultural and heritage features," Fairclough added. "It will enhance recreational opportunities and yield economic benefits in sectors such as tourism and wilderness outfitting."

The minister indicated that the strategy will help maintain the Yukon's wilderness areas, as well as wildlife and wildlife habitat. It will also provide greater certainty for resource-based industries.

The conservation initiative helps fulfill a number of commitments made over the past decade, including the Environment Act, Yukon First Nations Final Agreements, the Yukon Parks Systems Plan, the Whitehorse Mining Initiative and the Canadian Biodiversity Strategy.

"It's a living document. Yukon people own it, and Yukon people will make it work as we begin the process of identifying and selecting areas for protection," Fairclough said.

Copies of Wild Spaces - Protected Places are available from the Yukon government Inquiry Centre, Renewable Resources offices, community libraries and territorial agents and representatives.

Contact: Heather Finton, Media Liaison Officer, Cabinet Offices, (867) 667-8411.

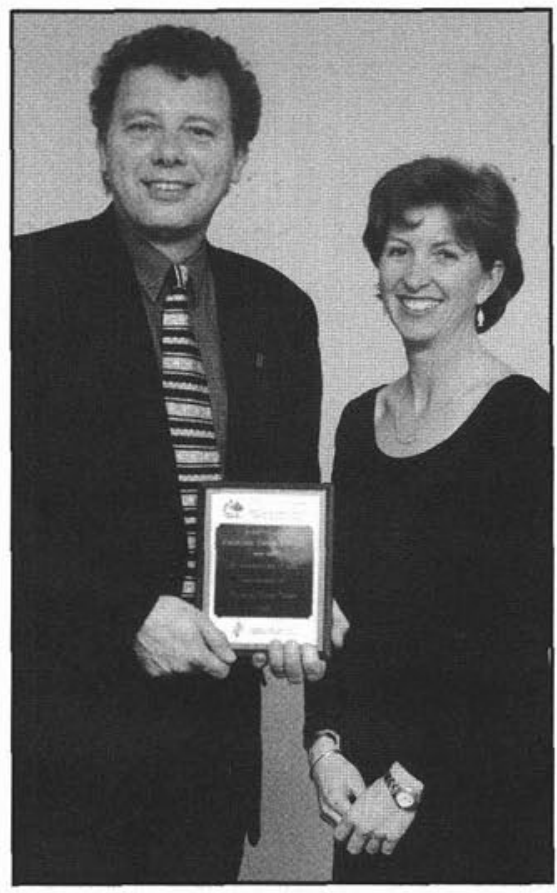

CFA President Susan Gesner presents Mr. Yves St. Onge of CFS with a plaque recognising his contribution to National Forest Week.

\section{First Report of Tomentosus Root Disease from the Yukon}

A 1997 forest pest survey in the Watson Lake area $\left(60^{\circ} \mathrm{N} 129^{\circ} \mathrm{W}\right)$ of the Yukon tentatively identified Inonotus tomentosus in association with white spruce, in trees dead at $25+$ years or showing root rot at 200 to 275 years. This is the first western Canadian report confirming this major conifer root disease north of about $55^{\circ} \mathrm{N}$ latitude. It now seems likely that I. tomentosus is much more widespread north of $55^{\circ} \mathrm{N}$ in western Canada than has previously been recognized. Infected trees may appear healthy but have extensive butt cull and reduced annual increment growth.

The fungus spreads from tree to tree at points of root contact. Inonotus tomentosus is a serious problem in secondgrowth stands as the stumps of infected trees provide an inoculum source for young trees. Contact Richard Hunt, CFS, Pacific Forestry Centre, tel. (250) 363-0640, e-mail: rhunt@pfc.forestry.ca. 


\title{
Reinventing the BC Forest Products Industry
}

\author{
12th Annual PricewaterhouseCoopers Forest Industry Conference, 9 March 1999, \\ Vancouver, BC
}

More than 400 forest industry delegates attended the 12th Annual PricewaterhouseCoopers Forest Industry Conference in Vancouver.

They heard predictions from Mike McCallum, Partner, PricewaterhouseCoopers, that the $\mathrm{BC}$ forest products industry will post unprecendented aftertax losses of \$1 billion in 1998. The market pulp sector was the biggest loser, accounting for $\$ 400$ million in after-tax losses. Profitability declined in every sector except newsprint, which reported profits of $\$ 50$ million.

Senior management in attendance were urged to work cooperatively with other forest sector stakeholders to "re-invent the $\mathrm{BC}$ forest industry." According to McCallum, BC pulp mills have labour and energy costs far in excess of their competitors and encouraged industry to collaborate with government and labour to bring costs in line so that the industry can get back on its feet once again.

Weyerhaeuser Company Chief Economist Lynn Michaelis predicted that U.S. housing starts would remain stable in 1999 but that a host of other factors will work against increases in world lumber prices. These factors include increased exports from international markets, the ongoing substitution of nonwood materials, high production costs, excessive government regulations, and the Asian economic meltdown. This situation may not abate for at least three years.

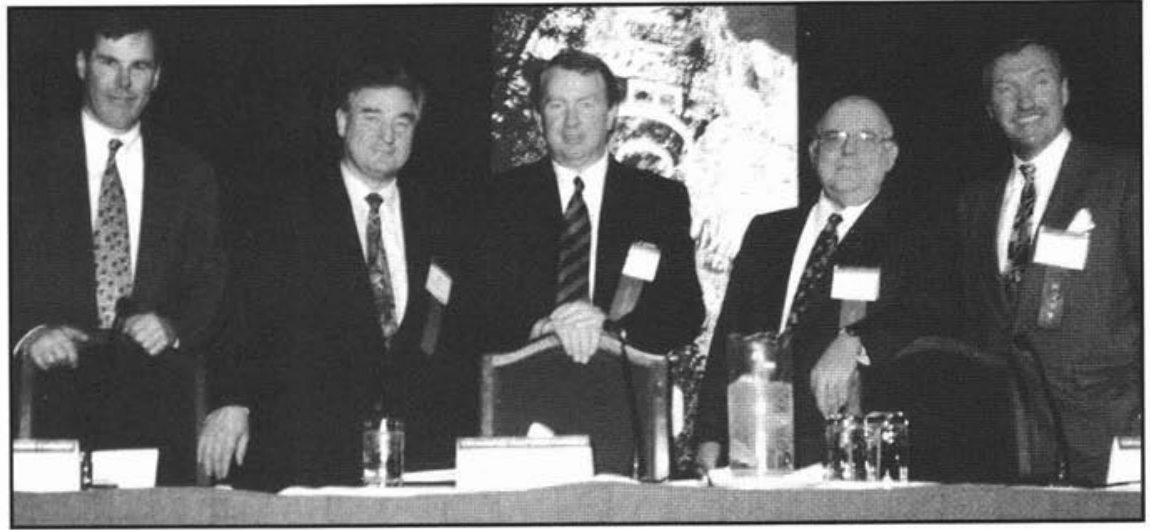

The President's Panel. L to R: Hank Ketcham, President/CEO, West Fraser Timber Co., Tom Stephens, President/CEO, MacMillan Bloedel Ltd., Bill Gaynor, President/CEO, Weyerhauser Canada Ltd., David Emerson, President/CEO, CANFOR Corporation, Doug Hayhurst, Session Chair, PricewaterhouseCoopers.

A panel, "Reinventing the BC Forest Industry", chaired by Bruce McIntyre, PricewaterhouseCoopers, included presentations by Ron MacDonald, President, Council of Forest Industries, Jonathon Mishkin, Donaldson, Lufkin, and Jenrette, Annette Verschuren, President, Home Depot of Canada, and Simon Bryceson, Public Relations Consultant.

MacDonald emphasized the BC government as being key to the continuing viability of many $\mathrm{BC}$ forestry firms, particularly regarding the unfavourable tax structures, stumpage rates, and other factors such as the difficulties in implementing the unwieldy Forest Practices Code. He suggested improved applications of the Code could save the industry a sub- stantial $\$ 600$ million. He emphasized further the importance of supporting agencies such as FERIC and Forintek and for establishing partnerships with labour.

Mishkin was pessimistic about the industry and saw no obvious catalyst to make the industry perform better. However, MacMillan Bloedel Ltd. reported a profit in 1998 by selling unprofitable mills, packaging and fibreboard plants, reducing staff by $14 \%$, and by lowering operating costs.

Verschuren said her chain of stores would work with suppliers to boost its inventory of products from well-managed forests. She opposes a boycott of coastal forest products promoted by eco-activists.

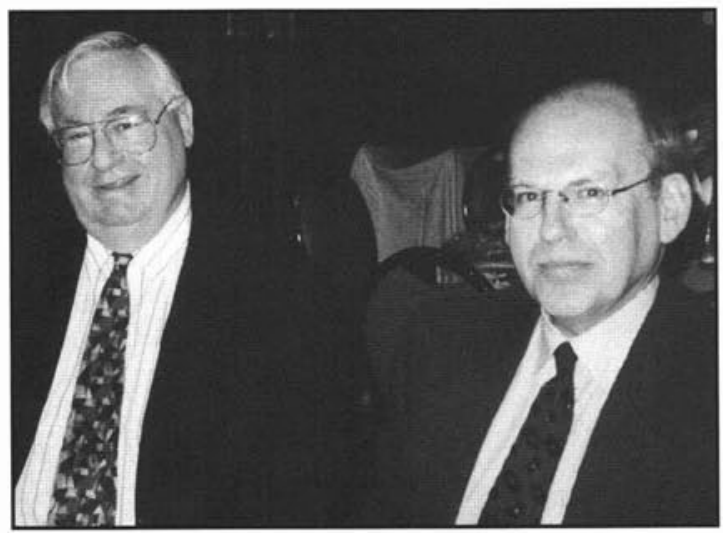

Mike Apsey (L), consultant and formerly Deputy Minister, BC Ministry of Forests, and John Allan, current Deputy Minister, BC Ministry of Forests.

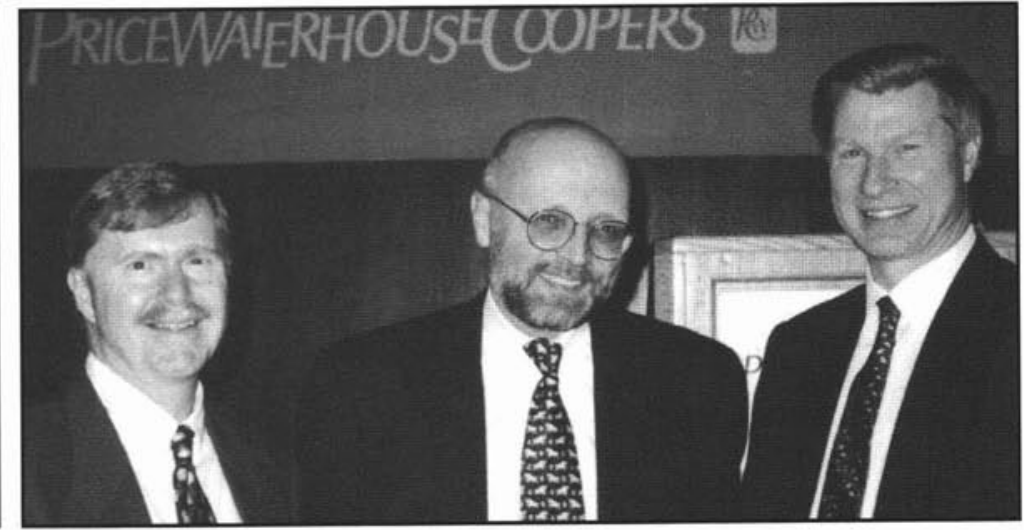

Bruce McIntyre, PricewaterhouseCoopers, Vancouver; Carl Steidtmann, PricewaterhouseCoopers New York, Conference Keynote Speaker; Gary D. Powroznik, PricewaterhouseCoopers, Vancouver. 
According to Bryceson, certification is inevitable and will come to dominate the forest industry not because the consumer wishes it, not because the industry seeks it, but because market economics will force it. Once it is in place, the use of noncertified products becomes damaging and causes a reduction in market share. At this stage, it would no longer be simply a marketing tool, and becomes a condition of entry to the market.

The President's panel included Hank Ketcham, West Fraser Co. Ltd., Tom Stephens, MacMillan Bloedel Ltd., Bill Gaynor, Weyerhaeuser Canada Ltd., and David Emerson, Canfor Corporation. Each of these CEOs was asked what needs to be re-invented in the $\mathrm{BC}$ forest industry. There was consensus on the need for a common vision by government and industry, the need for innovative leadership, the need to better communicate with society and the public, and on the urgent need for the industry to find the basis for profitability and to renegotiate key issues such as taxation, stumpage, and simplified regulations.

The CEOs are responding to improve the industry situation by consolidation, acquisitions, and mergers. However, the keynote speaker, Carl Steidtmann, PricewaterhouseCoopers, New York, pointed out the record on mergers is not always successful with $80 \%$ of mergers not meeting expectations. This is due mainly to a lack of synergy from the inadequate evaluation of crucial intangibles like culture, relationships, and information.

The word vision was mentioned several times during the conference, but none, with the exception of Tom Stephens, has detailed and implemented creative ideas as he has done for his company this past year. His Editorial in the March/April issue of The Forestry Chronicle is recommended reading.

V.J. Nordin, R.P.F., Editor

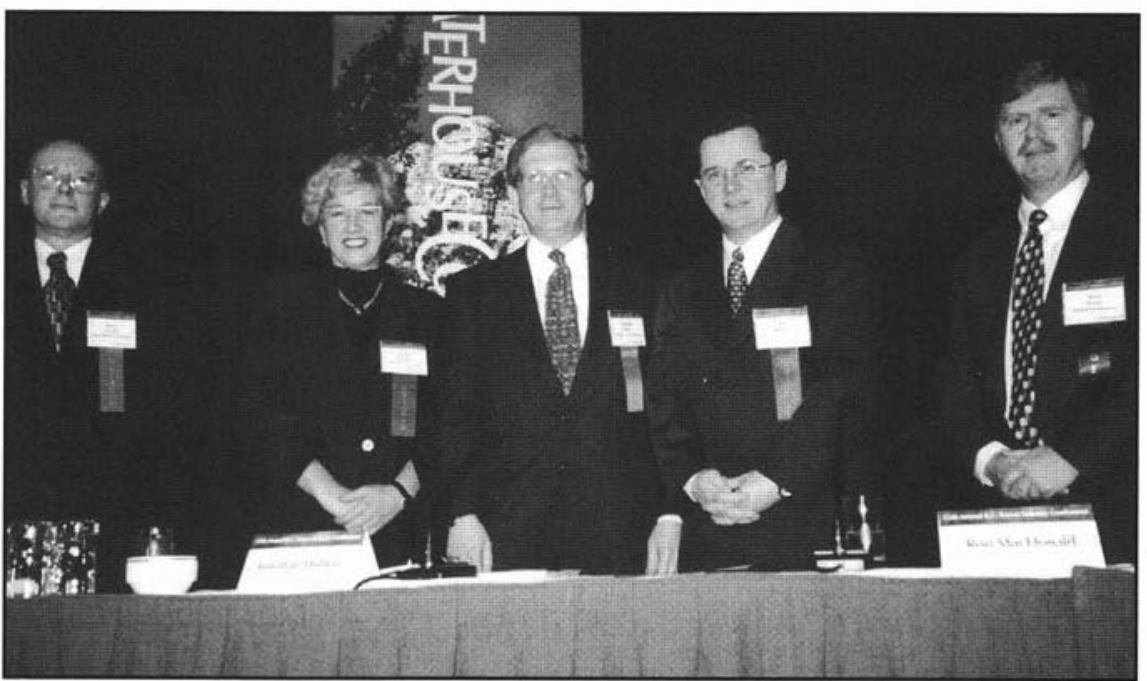

Panel on "Reinventing the BC forest industry." $L$ to $R$ : Simon Bryceson, Consultant, Public Relations; Annette Verschuren, President, The Home Depot Canada; Jonathon Mishkin, Donaldson Lufkin, \& Jenrette; Ron MacDonald, President/CEO, Council of Forest Industries (COFI); Bruce Mclntyre, Session Chair.
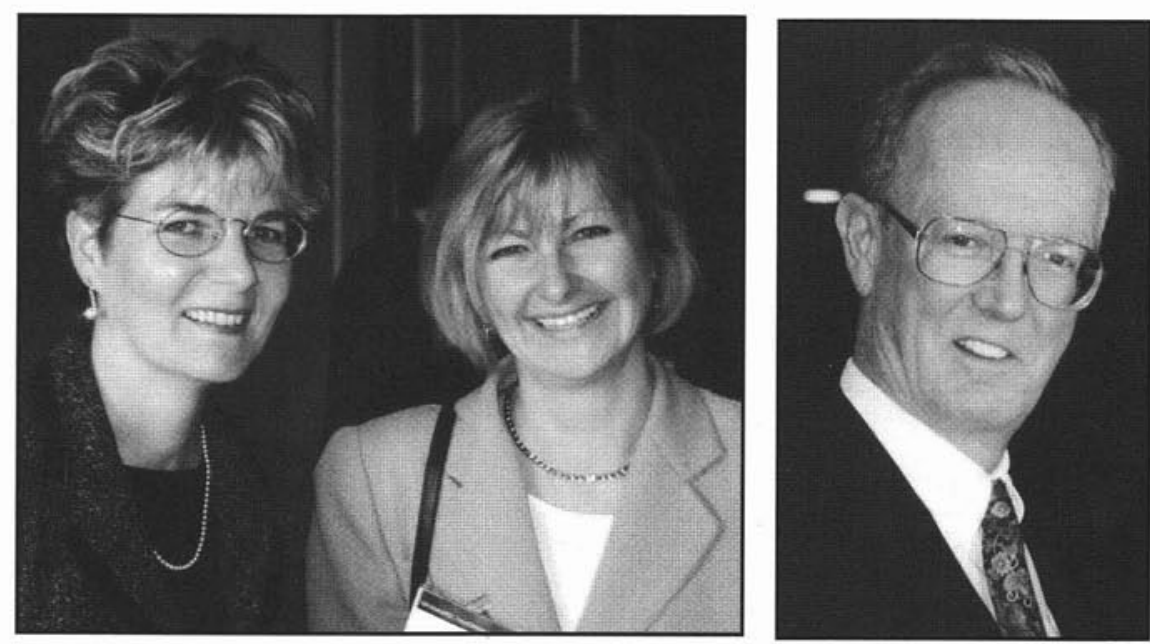

Above left, Jane E. Butterfield (L), PricewaterhouseCoopers, Vancouver and Beverlee F. Park, C.A., Controller, Timber West Ltd., Vancouver.

Above right, Conference delegate E.V. (Van) Scoffield, R.P.F., Executive Director, Association of $B C$ Professional Foresters.

\begin{tabular}{|c|c|c|}
\hline 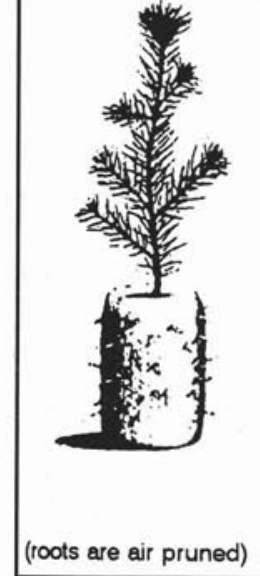 & $\begin{array}{l}\text { A Canadian container system that is: } \\
\text { - soft-walled for completely natural seedling root formation } \\
\text { - media and container all in one } \\
\text { - always a plug Jiffy } \\
\text { - plantable any time after germination } \\
\text { - designed to enhance plantation establishment } \\
\text { CONTACT: Jiffy Products (N.B.) Limited } \\
\text { PO Box 360, Shippagan, N.B., EOB } 2 \text { PO } \\
\text { Phone (506) 336-2284 Fax (506) 336-9609 }\end{array}$ & $\begin{array}{c}\text { Grow your } \\
\text { seedlings } \\
\text { with }\end{array}$ \\
\hline
\end{tabular}




\title{
Sylvicon'99 Conference - Looking into the 21 st Century
}

\author{
Fredericton, NB, 16-17 February 1999 \\ Sylvicon'99 Wrap-up
}

\section{Vidar Nordin, V.J. Nordin and Associates Inc. - Keynote Address}

Vidar began his presentation by reminding the audience that as foresters in New Brunswick look ahead to the next millennium, they are building on at least 300 years of forestry history in the Atlantic Region of Canada. He suggested that we should address the challenges of the next century by "Thinking Strategy, Thinking Leadership, Thinking Vision," Vidar invoked the image of Sun Tzu, the great Chinese warrior/philosopher. This was appropriate, given that the Sylvicon sessions were occurring during Chinese New Year, which is considered an appropriate time for looking back before looking ahead.

Even as he began his prognostication, however, Vidar cautioned that while we can identify trends by looking at what has happened in the past, the future can't be precisely predicted. Nonetheless, he contends that it is possible to help shape our futures by developing well-thoughtout strategies and through timely action.

Vidar reminded the audience that strategic directions are being developed and articulated by the entire forestry sector in Canada, and these are based upon extensive public participation. However, progress on action across the country is uneven, and there is inadequate vision on innovative ways to develop new partnerships and methods to turn wellmeaning policy into realistic action. He suggested, for example, that we need new partnerships for better forest research and forest management. He also suggested that foresters must do a better job of communicating with the public and with politicians. He argued that we all must do a better job of tying policy to implementation and rewarding leadership that is visionary and geared to action. $\mathrm{He}$ also felt that foresters and the forestry sector must do a better job of collaborating on common objectives.

Vidar then went on to discuss some forestry trends and their implications, including the likelihood that, in the 21st century the forest industry will be dominated by a few large firms, but that these firms will require responsive management and visionary leadership.

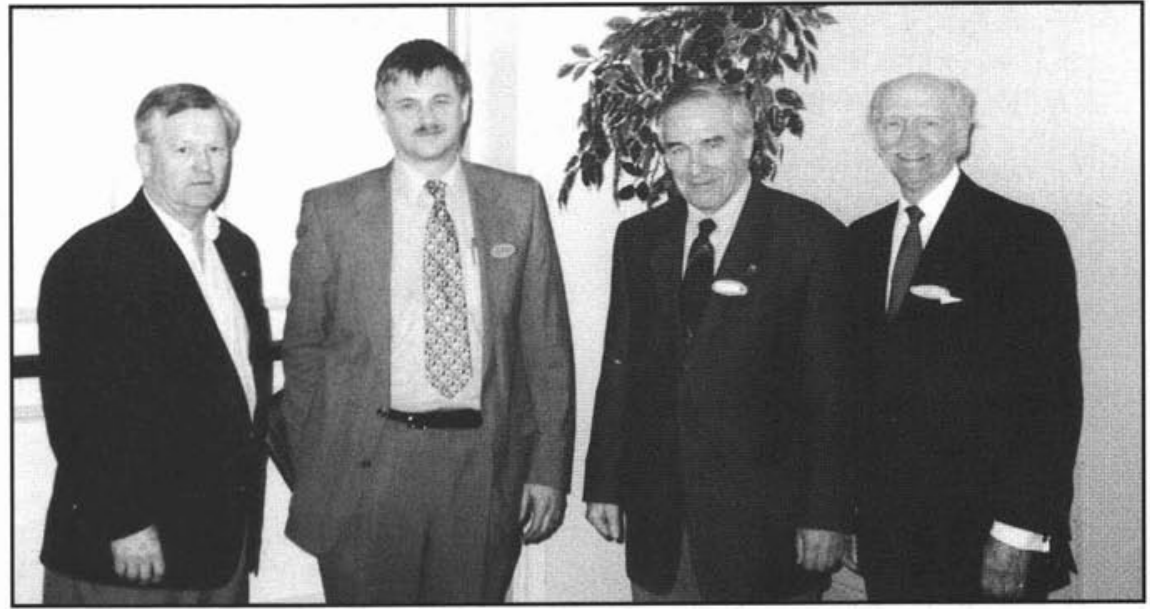

L to R: Tom Sifton, Executive Director, ARPFNB; Dr. Ted Robak, Sylvicon ' 99 summation speaker; Maxwell Carter, Executive Director, Forest Products Association of New Brunswick; Dr. Vidar Nordin, Sylvicon '99, Keynote Speaker.

\section{Robert Stewart}

Robert's presentation concerned global climate change and the implications for Canadian forestry. He began by comparing climate change prognostications with science fiction, where speculative concepts and competing forecasts abound, but some of which may become very real in our own lifetimes. He argued that there almost certainly is a human influence on climate change, and that some measurable change in our climate will occur regardless of the success of current attempts to mitigate the damage that we have caused.

As a result of this inevitable climate change, Canada's forests can be expected to change dramatically. Climate change has serious implications for the health and productivity of our forests. In turn, these will likely have large socioeconomic impacts. What is more uncertain, however, is how soon climate change will actually begin to affect our forests, and how

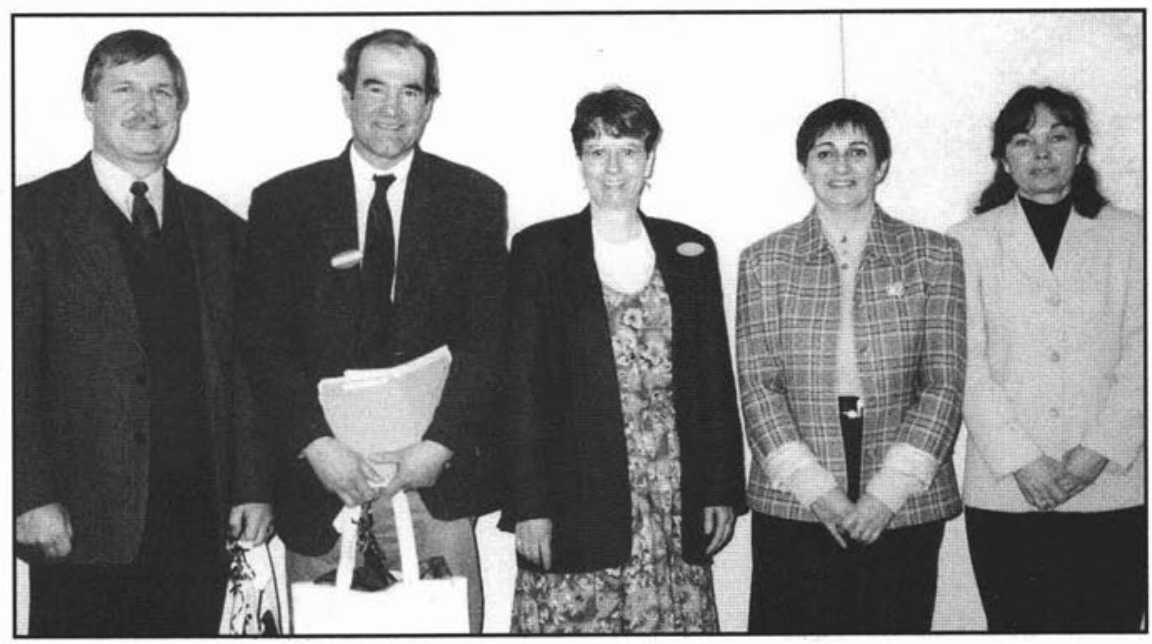

Sylvicon '99 Panel Speakers. L to R: Bob Stewart, Panel Speaker; David Palmer, Panel Speaker; Joanne MacDonald, Maritimes Section Chair; Lise Caron, Panel Speaker; Liz Rainer, Member at Large, ARPFNB. 


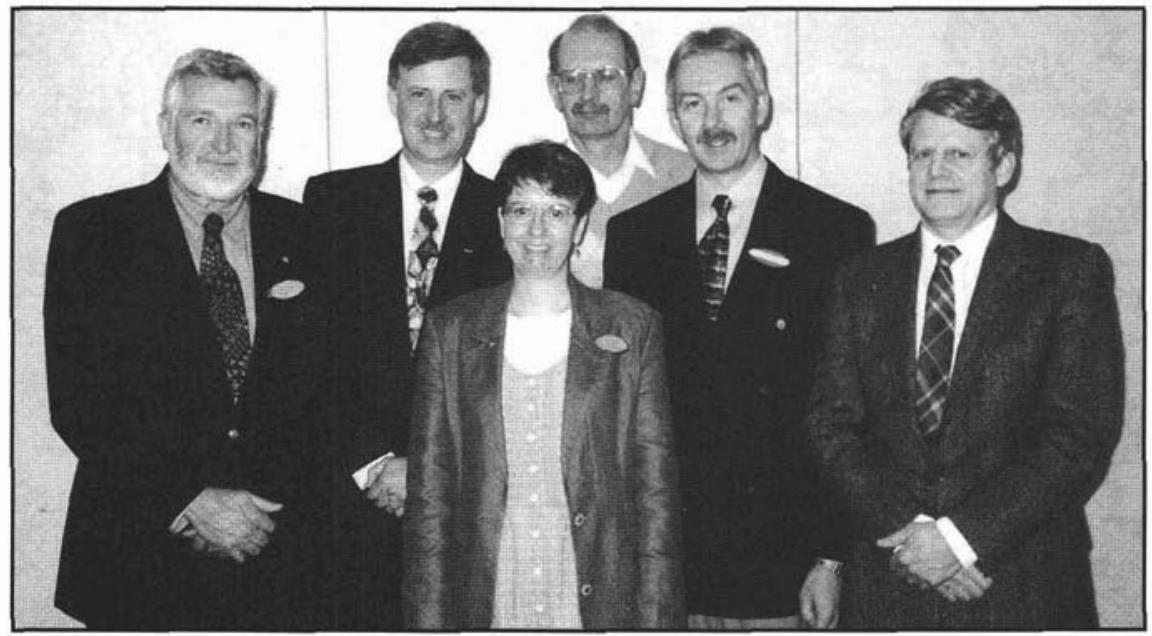

Maritime Section CIF, incoming officers. L to R: Ralph Roberts, Past President, CIF, National Executive; Jerry Dunlap, Vice-Chair; Joanne MacDonald, Chair; Darrell Hebb, Councillor; Dave MacLean, Director; Blair Vessie, Councillor.

quickly these changes will come. Our forests and industries can absorb change, but it is more difficult to adapt to sudden change without a great deal of stress and disruption.

Robert then went on to suggest some implications of climate change on our forest management processes. He began by suggesting that the tools and knowledge bases that are being developed now are what will be required to deal with climate change. The only caveat to this is that climate change is also likely to bring along surprises such as catastrophic weather events that are hard to incorporate in our planning. Nevertheless, he sug-

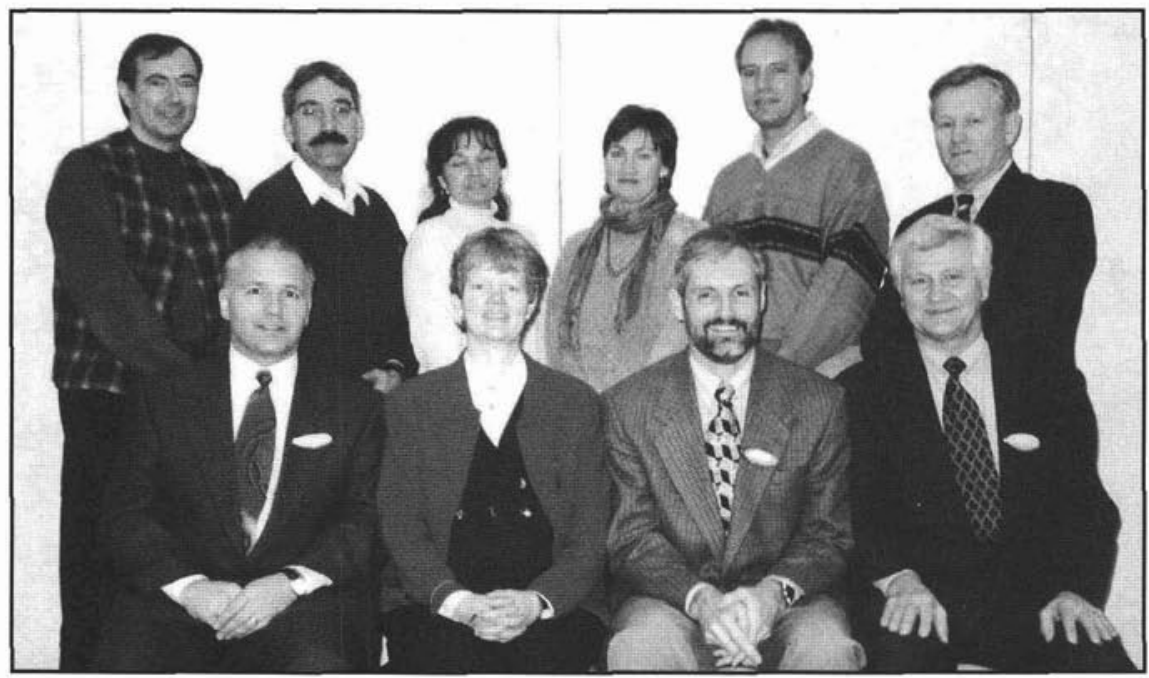

Incoming officers of the Association of Registered Professional Foresters of New Brunswick (ARPFNB). L to R: back row Gilles Couturier, outgoing Past President; Roger Roy, Member at Large; Liz Rainer, Member at Large; Laurie Doneff, Secretary/Treasurer; Bruce Beaton, Member at Large; Tom Siffon, Executive Director; front row Kevin Topolniski, Past President; Hillary Veen, Member at Large; Ron Smith, President; Rod O'Connell, Vice President. ecosystems are not stable, can be seen as completely nonsensical in the context of climate change.

\section{Dale Caldwell, Frasers}

Dale described the many uses of helicopters in Frasers' limits, but spent most time on their use as a public education tool. Frasers uses helicopters to give people from all walks of life a better understanding of the company's forest management practices. Through his presentation, we were able to "follow" a typical tour. Dale then described the usual reaction of tour participants, including how their opinions changed as a result of the exercise. In most cases, he suggested, the participants are very pleasantly surprised by what they see, and come away with a much better appreciation of what the company is doing. Dale pointed out how ignorant the public often still is about forestry, but since the industry needs the public's support it is up to companies to undertake such public education. Dale then gave examples of how tours can help the public understand what the real issues are, and what is being done.

\section{Tony Rotherham, CPPA}

Tony gave the audience his opinions on some of the major challenges faced by the forest industry as it enters the 21st Century. These include such issues as:

- Supply Chain Management - This requires that the entire production process, from forest to forest management to processing plants to markets, is well managed and integrated. If this "supply chain" is properly managed, all parties are happy with the relationships and all ethical and social needs are satisfied.

- Brand Image - More and more, as globalization blurs boundaries, the development of brand image becomes important for companies, for industry sectors and even for countries. The design, development and maintenance of brand image will become increasingly significant concerns for forest products companies and the forestry sector.

- Certification - This started out as a forest management issue but has become much more, and now includes aspects of public assurance, market acceptance, and so on. This complicates matters, but it is necessary to deal with such issues. The argument is often about who controls the certification process and related decision-making processes. Tony expressed his concern about the trend of allowing 
non-elected officials becoming the gatekeepers and controllers of such processes. He indicated that a large percentage of forest companies are moving towards some sort of certification (many towards ISO 14001).

- Climate Change-Given the current and expected growth of industry, the reality is that the Canadian forest industry must reduce greenhouse gas emissions by $30 \%$ in Canada to reach the targets set in Kyoto. There is a significant government and industry effort to develop a program to reach the target and the forest industry is doing its part. Unfortunately, the public is not interested, but they must become interested if the target is to be met. - Endangered Species - The federal legislation related to endangered species (Bill C-65) is now dead, but a new bill is expected. There will be a roundtable discussion of the legislation, as well as a roundtable discussion on dispute resolution mechanisms. Tony suggested that the forest industry needs to lobby to ensure that the law is balanced.

\section{Elizabeth Beal, APEC}

Elizabeth described the impact of the forest industry on the New Brunswick economy. She pointed out that the forest industry is New Brunswick's largest "industry cluster," constituting $8.9 \%$ of provincial GDP, which is twice the national average. Forest products make up $39.4 \%$ of provincial exports, or three times the national average. The New Brunswick industry recently exported 1.7 billion dollars worth of forest products to the United States, as well as 500 million dollars of products to other destinations. 1998 was a good year for the industry, generally. The export growth trend of forest products in the province is good, which is critical to the future of the province's economy, especially since the forest industry's economic multiplier is estimated to be 2.2. While this illustrates the importance of forest products to the New Brunswick economy, it also highlights the vulnerability of the province to downturns in the industry.

Overall employment in forestry in the province continues to grow. Forest industry jobs are more highly paid than the average for the province. There are problems, however. The industry can expect commodity prices to remain relatively low, and productivity levels for the industry are not great. Elizabeth reminded the audience that $84.7 \%$ of the province's land is forested. She also indicated that har-

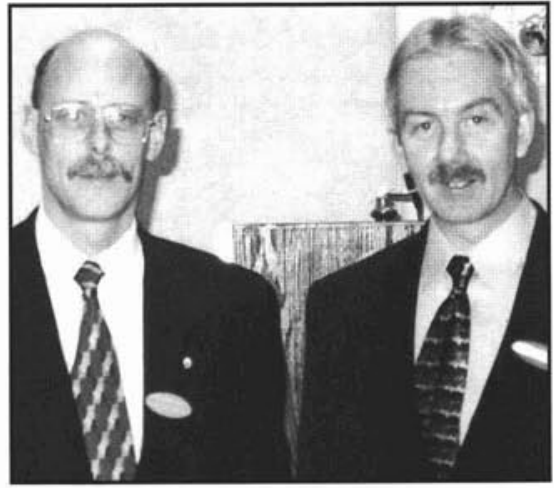

David Maclean (R), Chair, Maritime Section, C.I.F., presents a certificate to Dale Simpson, honoured as Section Member of the Year.

vesting rates are high and planting has been reduced, although someone in the audience pointed out that this might be the result of greater dependence on natural regeneration, along with a greater level of care in harvesting and a desire for more natural forests. In New Brunswick, forest management expenditures are higher (per hectare) than the national average. Most forestry jobs are in more rural areas, where they are more likely to be the dominant engines of the local economy.

\section{Dave Palmer, York-Sunbury- Charlotte Forest Products Marketing Board}

Dave used the current NB Protective Areas Strategy controversy as a case study. He stated that the 90 s became (or was supposed to become) the dawn of the area of structured public participation. There is supposed to be more emphasis on accommodation, less on confrontation. The idea was that policies would be based upon informed decisions and consensus. He then suggested that the Protected Areas Strategy debacle proves that there is a long way to go before this ideal can be achieved. He pointed out that there were many reactions to the proposed strategy, most of them predictable. The forest industry has mounted a concerted campaign against the PAS proposal, which appears to have been successful. Nevertheless, Dave says that the industry should be careful since a negative campaign can be risky and the science supporting the suggested potential job losses may be unsound. Overall, the possibility of a good, informed debate has been reduced dramatically because of the harsh reaction. With regard to job losses, Dave felt that more employment can come from increased value-added woodprocessing activity than may be lost to the

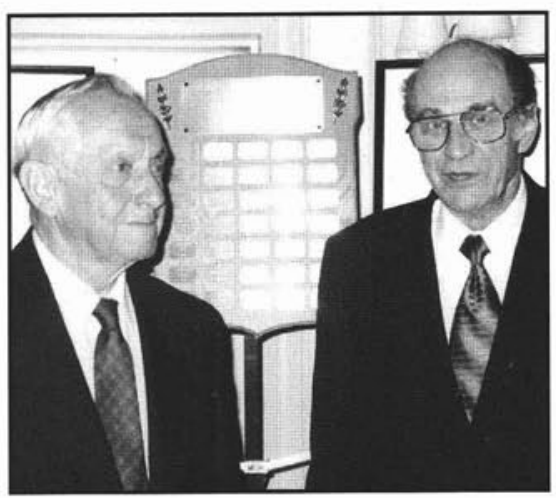

New inductees for the Hall of Fame in New Brunswick. William Sinclair Butler (L) and Art Van Slyke (R).

implementation of the Protected Areas Strategy. He also questions whether there is a direct correlation between amount harvested and numbers of jobs generated. Dave ended his talk by stating that the challenge is to step out of our present circumstances and ask ourselves how our decisions will be viewed by our children and grandchildren.

\section{Lise Caron, Université de Moncton}

Lise spoke about forestry education in the context of contemporary and future needs of forestry. She suggested that forestry issues are becoming increasingly complex and diverse. Our foresters must respond to these new challenges, and forestry educators must also change what they are doing. Lise believes that foresters and forestry professionals must lead the public debate regarding forestry in the next century. For this reason, the forester of the future must:

- be better at written and verbal communication;

- improve their ability to deal with different languages and cultures;

- have a better understanding of concepts of efficiency and value-added;

- improve their knowledge of economics and marketing;

- be able to be good applied researchers;

- be comfortable with new technologies;

- be able to adapt;

- be conceptual thinkers.

There is a long list of things that the new forester must be able to handle, and educators must develop new ways to develop the new forestry professional. Lise argued that forestry educators must develop new partnerships with the public and private sectors in order to accomplish these goals. 


\section{Continuing Forestry Education in Alberta}

The Alberta Advanced Forest Management Institute (AAFMI) just completed the fourth delivery of Module IV. This 2-week module is one in a series of a six-module program offered by AAFMI at the Environmental Training Centre in Hinton, Alberta. Twenty-seven candidates attended this module, which is entitled "Silviculture Planning and Practices."

The classes are composed of students from government, forest industry, forestry consulting firms, and post secondary educational institutions. Information delivered in Module IV includes a variety of silviculture learning principles such as stand density management, crop planning, strategies to reduce risk, fertilization, wood quality, and so on. Information delivered in each module consists of a mixture of lecture presentations, class project work, field trips and a variety of individual evaluation processes. With some exceptions, candidates in the program are graduate foresters or graduates from a two-year forest technology program who have a considerable amount of diverse forestry-related experience. As a rule, participants will have completed Modules I to III in the series prior to registering for Module IV.

This module was facilitated under the capable guidance of Dr. Keith McClain. Faculty was recruited from Alberta, British Columbia and from as far away as South Carolina. Students successfully com-

Below, Dr. Keith McClain (Facilitator, with tie) assisting Module IV students with crop planning exercise.

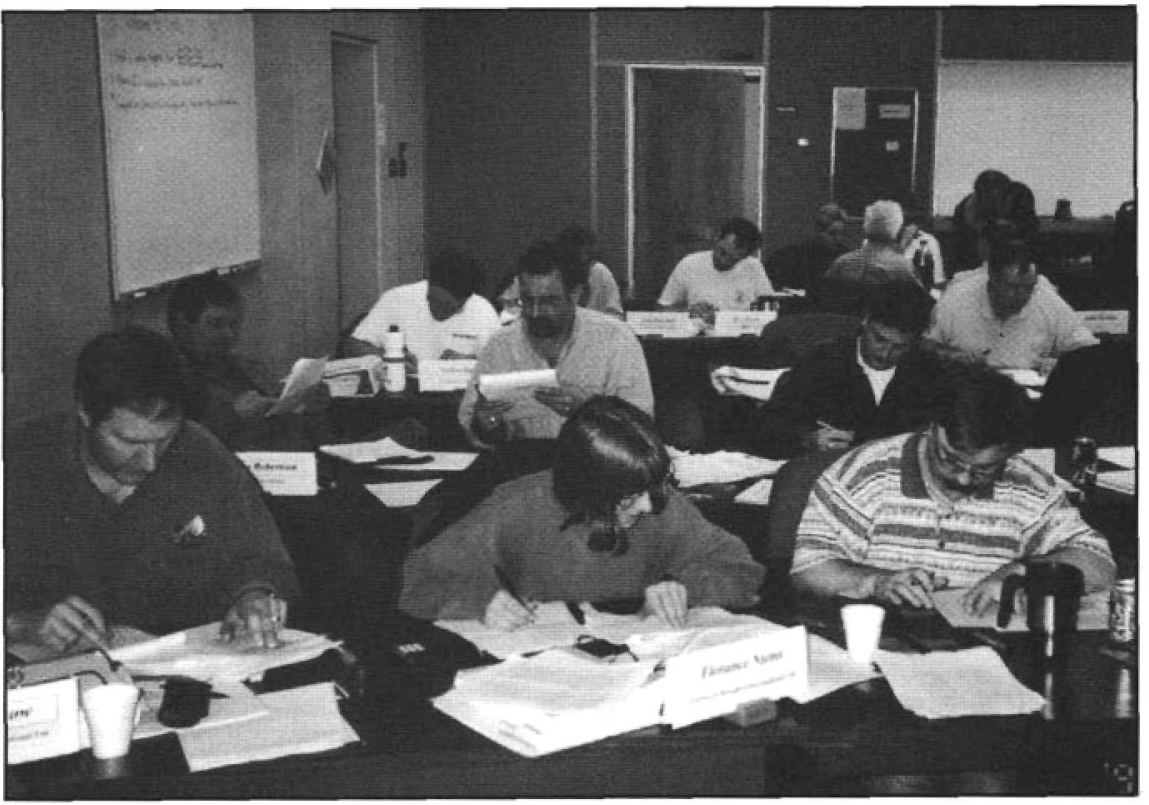

Module IV class working on a stand density management project. Front row (L to $R$ ) Steve Luchkow, Florence Niemi, and Bruce Avery.

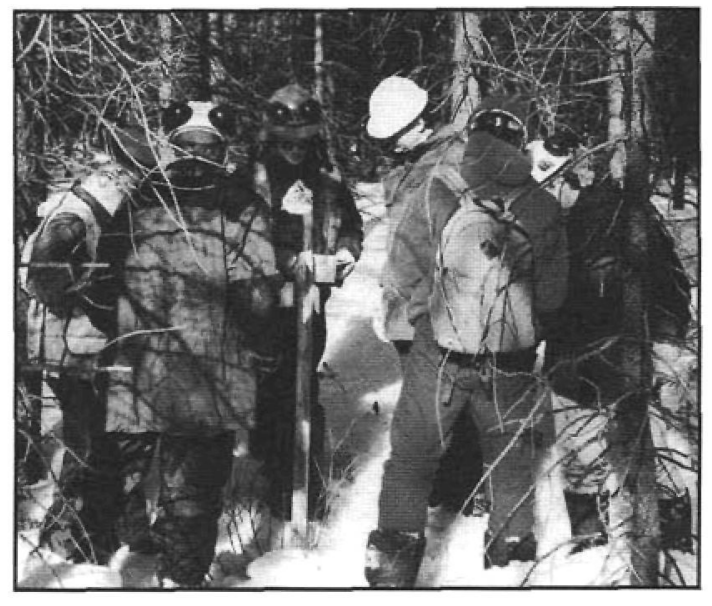

Left, Module IV students on a field trip collecting data to be used in the development of a crop plan.

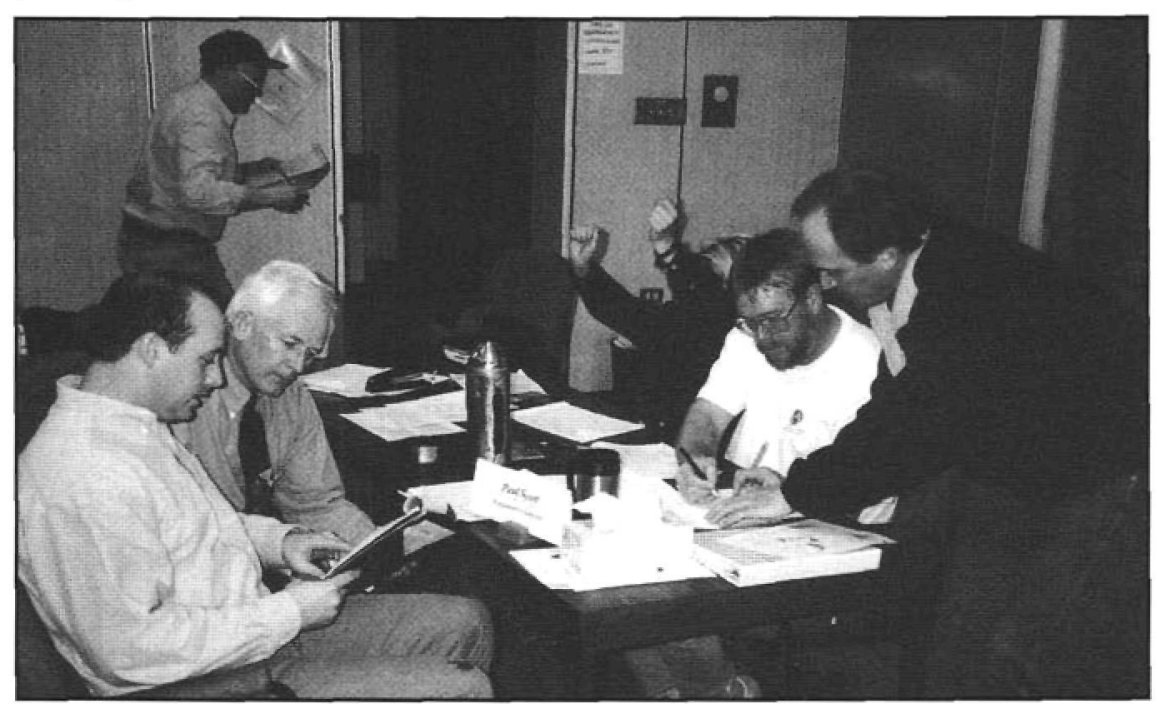

managers the opportunity to be exposed to, interact with and absorb state-of-theart technology delivered by researchers, scientists, academics and highly experienced field foresters. The intent is to raise the bar on thought processes that forest managers use to devise silviculture strategies and forest management planning.

Interest remains high for attending such programs. Module I in the next series will be offered again in June 1999, and to date, 24 candidates have registered. It is a great opportunity for managers to supplement their formal education and enhance their field experience.

For more information, contact Jim Friesen at the Environmental Training Centre. Phone (780) 865-8228, Fax (780) 865-8341, E-mail Jim.Friesen@gov.ab.ca. 


\section{CESO Needs more Forestry Volunteers for Overseas and Domestic Assignments}

"In 1995 CESO sent me to Chile as a Volunteer Adviser to Fundacion Chile. There I helped the plantation forest industry assess new national environmental legislation. Fundacion Chile is similar to the Council of Forest Industries in $B C$ and other industry alliances in Canada. My work was with Chilean foresters in numerous radiata pine forests and harvesting operations, universities, and government agencies in Concepcion and Santiago. These folks were wonderful to work with. I had a ball!"

\section{P. Duffy}

CESO (also known as Canadian Executive Service Organization) needs more volunteers in forestry to meet demands generated by requests from the 40 developing countries which it serves.

CESO is a Canadian not-for-profit organization which sends out volunteers with senior level experience to serve as advisers and trainers to enterprises in disadvantaged economies which cannot access paid consultants.

Volunteers work in Canadian Aboriginal communities, developing countries and in the new market economies of Central and Eastern Europe and of the Former Soviet Union. Examples are Hungary, Bolivia, Peru, Belarus, and Poland. Assignments overseas can be of 3-4 weeks duration and Canadian Aboriginal ones average seven days.

Every year CESO undertakes about 2000 assignments in some 40 countries including Canada. Since 1967 it has completed more than 32000 assignments with clients worldwide.

Volunteer advisers are Canadians who have a lifetime of business, technical or professional experience to share. They must have a proven track record in their field and be willing to provide practical knowledge for no pay.

There are more than 4000 Volunteer Advisers on CESO's roster in more than 150 industry/professional classifications. However, there are only 46 who are identified in the forestry category. And CESO is very interested in building up the roster in forestry.

CESO is funded by the Canadian government, about 300 corporations, its clients, multilateral agencies and several hundred individuals. Volunteers do not receive a salary. Travel expenses, accommodation, food and local transportation are paid and spouses can accompany the Volunteer Adviser.

If CIF/IFC members wish to look into this rewarding type of volunteerism, call Ms. Nicole Gold, Roster Manager, at CESO/SACO at 1-800-268-9052 Ext. 223 or (416) 961-2376 Ext. 223 in Toronto or e-mail at ngold@ceso-saco.com

\section{SACO Recherche d'autres conseillers forestiers en vue d'affectations à l'étranger et au pays}

\begin{abstract}
“En 1995, SACO m'a affecté au Chili comme conseiller volontaire auprès de la Fundacion Chile où j'ai aidé l'industrie de la plantation forestière à évaluer une nouvelle législation environnementale nationale. La Fundacion Chile est un organisme semblable au Council of Forest Industries en Colombie-Britannique et à d'autres alliances industrielles au Canada. Mon mandat consistait à travailler auprès d'experts-forestiers chiliens dans plusieurs forêts de pin de Monterey et exploitations forestières, d'universités et d'agences gouvernementales à Concepcion et Santiago. Ces gens ont été formidables. J'ai eu beaucoup de plaisir."
\end{abstract}

$$
\text { P. Duffy }
$$

SACO (également connu sous la désignation Service d'assistance canadienne aux organismes) est à la recherche de volontaires additionnels en sciences forestières afin de satisfaire les demandes en provennance des 40 pays en développement qu'il dessert.

SACO est un organisme canadien sans but lucratif qui affecte des bénévoles possédant une expérience de haut niveau afin qu'ils agissent comme conseillers et formateurs auprès d'entreprises dans les économies défavorisées qui n'ont pas les moyens d'avoir recours à des consultants rémunérés.

Les volntaires œuvrent dans les collectivités autochtones du Canada, les pays en développement et les nouvelles économies de marché de l'Europe centrale, de l'Europe de l'Est et de l'ancienne Union soviétique, notamment la Hongrie, la Bolivie, le Pérou, le Bélarus et la Pologne. La durée des affectations à l'étranger est de 3 à 4 semaines alors que les affectations dans les collectivités autochtones au Canada sont de sept jours en moyenne.

Chaque année, SACO entreprend environ 2000 affections dans quelque 40 pays, y compris le Canada. Depuis 1967, il a réalisé plus de 32000 affectations auprès de clients à l'échelle mondiale.

Les conseillers volontaires sont des Canadiens et Canadiennes qui possèdent toute une vie d'expérience commerciale, technique ou professionnelle qu'ils sont disposés à partager. Ils doivent jouir d'une réputation bien établie dans leur secteur d'activité et accepter d'offrir des connaissances pratiques sans rémunération.

Plus de 4000 volontaires provenant de plus de 150 classifications profession- nelles/industrielles sont inscrits au répertoire de SACO. Toutefois, seulement 46 de ceux-ci font partie de la catégorie forestière. Et SACO souhaite vivement accroître le nombre de conseillers forestiers.

SACO est financé par le gouvernement canadien, environ 300 grandes entreprises, ses clients, des agences multilatérales et quelques centaines de particuliers. Les volontaires ne reçoivent aucune rémunération. Leurs frais de déplacement, d'hébergement, de restauration et de transport local sont payés et les conjoints peuvent accompagner les conseillers volontaires.

Les membres de l'IFC/CIF qui souhaitent explorer ce genre de bénévolat gratifiant sont invités à communiquer avec Mme Nicole Gold, directrice du répertoire, SACO/CESO au 1-800-268-9052, poste 223 ou au (416) 961-2376, poste 223, à Toronto, ou par courrier électronique: ngold@ceso-saco.com. 


\section{Historic Internet Lumber Trade}

\section{TALPX ${ }^{\mathrm{TM}}$ Brings Internet Trading to Lumber and Panels}

On April 5 1999, TALPX Inc. introduced its revolutionary Internet-based, electronic lumber and panel exchange, according to President Jim Olmedo. The first trade - between Riverside Forest Products Ltd., a Kelowna, BC-based lumber and plywood producer and Jasper Lumber Company, Inc. an Atlanta, GA-based retailer - sent a rail car of SPF $2 \times 4$ studs across the Canadian-US border to the largest home-building market in the US. "I really felt like we made history today," Olmedo said.

"It was an exciting moment for our company and our pioneer members. The trade went off without a hitch, like we have been trading for months - a tribute to our team and our members," he added. "I believe that this is the beginning of an era in the forest products industry," he continued. "Advances in computer technology, the Internet and e-commerce technologies have gained ground in many industries. I believe it is time for the forest products industry," he said.

"This is just the first step in our journey in becoming the premier business-tobusiness e-commerce partner to the forest products industry," Olmedo said. "This first trade brought us closer to our goal of providing an efficient electronic marketplace for commodity softwood lumber and panels across North America."

Judy Johnston of Riverside remarked, "We were very excited to complete the first trade! The trade was quick, easy and convenient and the system is user friendly." Leigh Niolon of Jasper Lumber Company, Inc. added, "Being a participant on the first day of trading with TALPX ${ }^{\mathrm{TM}}$ was an exciting experience. As TALPX $^{\mathrm{TM}}$ develops, it has the potential to be an invaluable tool for the lumber industry."

The second trade - a rail car of $2 \times 10$ Hem Fir - was coast to coast, linking the Stober/Haddonfield operation in Cherry Hill, NJ with Crown Pacific a Portland, OR mill for the first time. Joe Todd of Stober commented, "TALPX" gave me the opportunity to buy direct from Crown Pacific, something I had not done before. The trade was convenient - I didn't have to write out a PO." Darrel Hanson of Crown Pacific added, "the trade was simple, direct and quick."

Pioneer members represent 1.4 billion board feet of lumber and panel production, and $\$ 1.2$ billion in retail sales. Members in the sign up process account for another 2 billion board feet of lumber, 300 million square feet of panels and more than $\$ 2$ billion retail sales. They are expected to be active this spring. Membership includes some 25 companies, representing over 200 locations, and is

"TALPX' ${ }^{\mathrm{TM}}$ was developed by lumber and panel people for lumber and panel people. We designed TALPX ${ }^{\mathrm{TM}}$ with traders in mind, making the system fast, reliable, secure and user friendly," Olmedo said. "Our sales team brings $300+$ years comgrowing daily. bined industry experience directly to our members. Our help desk is available to members toll free and is fully staffed with technical experts. We personally train our members in our Chicago Training Center to ensure they are prepared to take full advantage of TALPX ${ }^{\mathrm{TM}}$. We believe this is the right system, the right team and the right time for our industry." Olmedo concluded.

TALPX ${ }^{\mathrm{TM}}$ Inc., headquartered in Chicago, with regional offices throughout North America, is a business-tobusiness e-commerce partner to the lumber and panel industry, providing an Internet-based electronic exchange.

\section{New Forestry Regulations in Saskatchewan}

Saskatchewan's forestry industry starts cutting by a new set of rules as tough new provincial legislation kicks in.

The Forest Resources Management Act and accompanying regulations give the public a formal say in how forests are harvested and managed. The law also gives some teeth to enforcement, raising fines for those who violate the act to a whopping \$1 million from just \$2000.

Environment Minister Lorne Scott said the legislation will protect the forest ecosystem and balance the needs of forestry companies with the wishes of people who use the land. He said the new law is among the most "comprehensive and forward looking" in North America.

Under the Act, companies must totally reforest cut areas, and there will be three levels of planning before cutting is approved, with public consultation at each stage.

\section{Stora Inc., Nova Scotia, First to Receive ISO 14001 Certificate}

Stora Port Hawkesbury became the first forestry operation in Canada to receive ISO 14001 certification. The certification process included both company personnel and contract workers on Storacontrolled land, and covered the firm's environmental system for forest planning, road construction, harvesting and silviculture. 


\section{PREMIER AVIS}

\section{Conférence du millénaire pour le secteur des forêts}

\author{
Du 14 au 18 mai 2000 \\ Thunder Bay, Ontario
}

Un comité de direction a été constitué et les préparations ont été amorcées en vue de la tenue d'une conférence pour les dirigeants et les professionnels du secteur des forêts de partout au Canada au mois de mai de l'an 2000.

Le programme de la conférence est ambitieux. La conférence réunira un vast éventail de personnes et d'organisations qui sont directement concernés par l'avenir des forêts du Canada. Les organisateurs de la conférence ont établi les objectifs suivants:

Faire le point sur l'actualité dans les domaines de la science-technologie, des pratiques et des politiques forestières, de la société et de la gestion des forêts;

Promouvoir la discussion et l'interaction pour favoriser l'élaboration d'une vision commune au sujet de nos forêts parmi les participants eet leurs commettants.

Les personnes et les organisations intéressées à participer à cet événement ou à le parrainer sont priés de communiquer avec l'une ou l'autre des organisations et personnes dont les coordonnées sont indiquées ci-dessous. Le Comité organisateur sera heureux de faciliter la tenue de réunions du secteur des forêts avant et après la conférence, à Thunder Bay.

Association forestière canadienne Télé: (613) 232-1815 cooligd@gov.on.ca

Lakehead University Faculty of Forestry and the Forest Environment Télé: (807) 343-8507 David.Euler@lakeheadu.ca

Capitale forestière du Canada Télé: (807) 628-8251 fcc-2000@microage-tb.com

\title{
Causes of Growth Changes in European Forests
}

\author{
Public Seminar and Start-Up Meeting of the EC Research Project \\ RECOGNITION in Freiburg, 15-18, April 1999
}

In the 1980 s there was concern that Europe's forests were dying. Extensive surveys found evidence of some patches of moribund trees and evidence of needle losses. In the late 1980 s, rather paradoxically, some national researchers in Europe reported that trees appeared to be growing faster. The European Forest Institute assembled many of these researchers into a pan-European research team, which studied the matter in depth. EFI published its results in 1996 and showed that over much of Europe trees have indeed been growing much faster during recent decades. Some exceptions seem to lie on the periphery of Europe where the signal is less strong.

It matters very much what is causing this growth increase. Some causal processes could decrease long-term sustainability of forests and forestry in Europe. The European Forest Institute funded a pilot study into the possible causes. The study used existing ecological models to clarify if the magnitude of the increase could be confidently assigned to one or more causes. That study concluded that hypothesized causes such as nitrogen deposition, carbon dioxide fertilisation, increases in temperature and rainfall and changes in land use could have been responsible, but the study could not decide which was the primary factor or factor combination, nor could it account for the full magnitude of the observed increases.
The European Forest Institute, together with 24 collaborators from all across Europe, therefore, approached the European Union with a research proposal to determine the causes. EFI and its collaborators were delighted when the ECFAIR programme agreed to fund the research activity. The project "Relationships Between Recent Changes of Growth and Nutrition of Norway Spruce, Scots Pine, and European Beech Forests in Europe" goes under the acronym of RECOGNITION.

The Research Team is having its startup meeting in Freiburg on 15th to 18th April 1999. The meeting will commence with a public seminar, 15th April 1999, at which the state of knowledge, the underlying research hypotheses of the project and the way in which the project will work, will be more fully explained. All interested parties are invited to attend that public session. They should signal their intention to attend by communicating with Dr. Heinrich Spiecker, The Institute for Forest Growth, University of Freiburg, Bertoldstr. 17, D-79085 Freiburg im Breisgau, Germany, Tel: +49-761-2033737, Fax: +49-761-203-3740, e-mail: Internet: http://www.forst.uni-freiburg. de/Waldwachstum or Director Ian Hunter, European Forest Institute, Torikatu 34, FIN-80100 Joensuu, Finland, Tel: +35813-252020, Fax: +358-13-124393. E-mail: ian.hunter@efi.fi, Internet: http/www.efi.fi

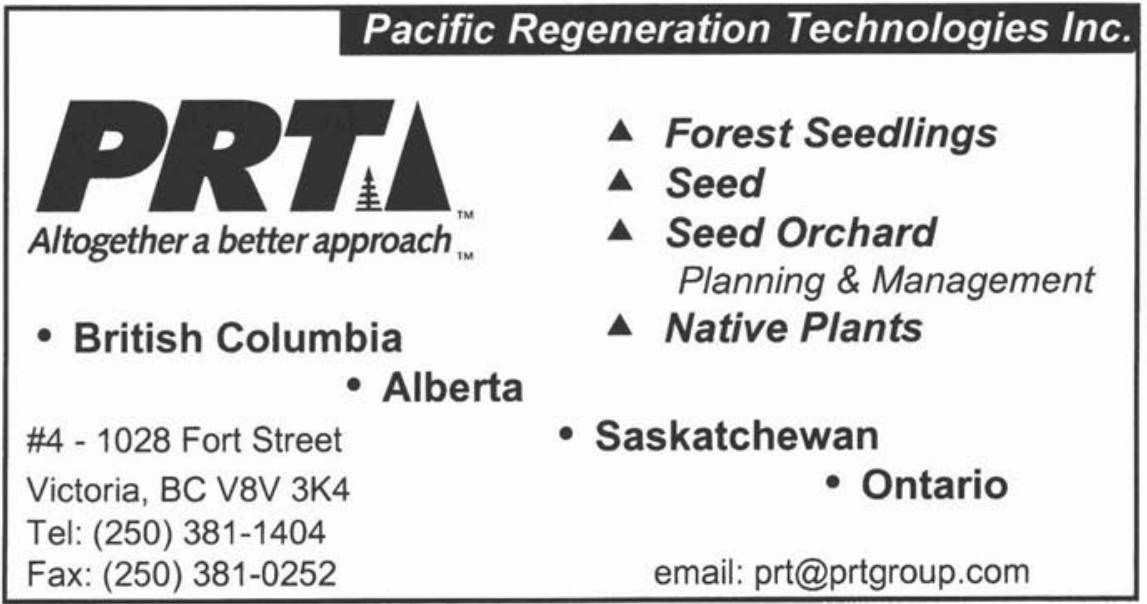




\section{Canadian Forestry Association Appoints First Woman President in Hundred Year History}

The Canadian Forestry Association (CFA) appointed a woman as its President for the first time in its 100-year history at its annual meeting in Ottawa on April 16, 1999. Ms. Susan Gesner, of Caledon East Ontario, took over the post after two years as the assocation's Vice President.

"I am really happy to have the opportunity to serve Canada's forest community at the beginning of the new Millenium," said Ms. Gesner after her appointment. "Forests are an integral part of Canada's culture, economy and environment and all Canadians have a role to play in determining how they are managed."

The CFA was established in March of 1900 and has played an important role in forest policy, education and public understanding of the nation's forests throughout its history. The mandate of the CFA is to promote good forest management and public understanding of Canada's forests. The association works with various nongovernment, private and public sector agencies on public education programming.

The CFA sponsors a number of programs that foster public understanding of Canada's forests including Smokey Bear, National Forest Week, Envirothon and Forest Capital of Canada.

"One of my main challenges as president will be to prepare the CFA for its

\section{Ontario's Living Legacy: A Complete Parks System}

Premier Mike Harris recently announced the biggest expansion of parks and protected areas in the history of Ontario.

Ontario's Living Legacy strategy will add 378 new parks and protected areas totalling 2.4 million hectares - increasing the area covered by parks and protected areas in Ontario by one-third. The Harris plan includes nine signature sites, enhancements to outdoor activities and international marketing potential. The total protected area in Ontario will increase to 9.5 million hectares - equivalent to all of southern Ontario south of Algonquin Park. Ontario is protecting 12 per cent, which is based on the standard set by the United Nations. It is the goal endorsed by the federal government. The Living Legacy strategy builds on the work of the Lands for Life consultation process. The government has accept-

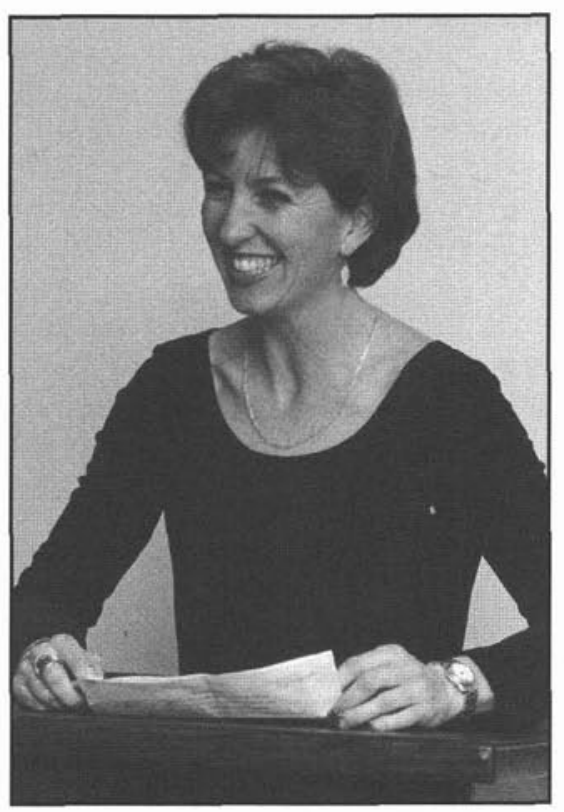

CFA President Susan Gesner

second century," added Ms. Gesner. "I am really optimistic about the future of our forests and look forward to working with people from all walks of life to make sure they remain healthy for future

For more information contact Dan Cooligan, R.P.F., Manager, National Programs, Telephone: (613) 232-1815, www.canadianforestry.com.

ed fully or in principle 213 of the 242 Lands for Life recommendations and continues to study a further 25 . More than 65000 Ontarians responded to Lands for Life and provided valuable input.

See Intensive silviculture - Part of Ontario's new 'Living Legacy' by R.A. Lautenschlager on page 535.

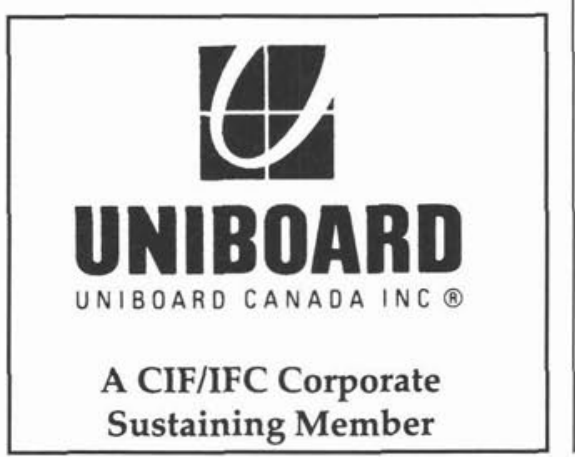
generations."

\section{UBC Centre to Shape Canada's Future Wood Industry}

Canadians moved further from the status of hewers of wood when the national Centre for Advanced Wood Processing (CAWP) opened at UBC April 9. The centre is the result of a national initiative to add value to Canada's most important natural resource.

"Technology, environmental concerns and globalization have brought Canada's wood industry to a crossroads," says centre director Tom Maness. "Our future prosperity depends increasingly on knowledge, new technologies and a highly skilled workforce which is prepared to innovate."

CAWP - in UBC's new $\$ 47.5$ million Forest Sciences Centre - contains a stateof-the-art secondary manufacturing pilot plant and complete industry education centre. The opening is being staged among the high-tech moulders, saw and computeraided design and manufacturing labs housed in the unique educational centre in Canada.

The first 10 graduates of the Centre's Bachelor of Science in Wood Products Processing program, who are in very high demand in industry, will be at the opening.

The industry-driven degree program trains specialists in wood engineering and processing, with a strong focus on internship. The five-year undergraduate degree features up to 19 months of carefully selected work experience. Job offers and requests for co-op students are pouring into the centre.

The centre also provides workshops, seminars and training in advanced manufacturing to transfer the latest technology to industry. As well, it conducts industry-supported applied research projects and provides consulting services, technical support and customized training programs.

CAWP was created in 1996 by a joint partnership among UBC, industry and senior levels of government and is guided by its industry advisory board, the National Education Initiative of the Furniture and Wood Products Manufacturing Industry. 


\section{Heroes of Canada's Forests Recognized by National Conservation Partnership}

36 Awards presented in first year of the Forest Stewardship Recognition Program

Thirty-six individuals, organizations and companies are being recognized for their outstanding efforts in forest management and conservation by the Forest Stewardship Recognition Program (FSRP). Launched as an Ontario pilot project in 1998, the FSRP is intended to promote awareness and appreciation of good stewardship, sustainable forest practices and biodiversity conservation.

The first year of the program has been a great success. "The range of activities being recognized is more than we had hoped for," says David Neave, Executive Director of Wildlife Habitat Canada. Award winners include a property owner in southwestern Ontario who has restored a marginal farm to forest by planting more than 100000 trees during the past 50 years; a logger who personally halted harvesting that threatened the nest of a rare northern goshawk; and, a forester in Timmins who modified culverts at his company's stream crossings to allow spawning fish easy passage. "By recognizing these fine efforts we all win," says Neave. "Their good work in land stewardship, sustainable forestry and conservation will inspire others to do the same."

All award winners receive a limited edition print of a painting by $\mathrm{BC}$ artist Don Li-Leger entitled New Morning. Presentations will be made to the recipients at various events during the next few months.

Current national FSRP partners include the Canadian Pulp and Paper Association, the Canadian Forest Service and Wildlife Habitat Canada. Numerous other government, forestry and conservation groups have helped promote the program in Ontario during its first year, including the Ontario Ministry of Natural Resources. New partners are now being sought across Canada. "Our goals are to involve at least two more provinces this year and to expand to a national program by 2001," says Eric Boysen, Manager of the FSRP. "We're inviting all organizations with an interest in land stewardship and conservation to join us in preserving the biodiversity of Canada's forests."

The Forest Stewardship Recognition Program also has the support of Canada's Governor General. His Excellency, the Right Honourable Roméo LeBlanc, is an official patron of the program.

For more information contact: Eric Boysen, Manager, Forest Stewardship Recognition Program, or, Jennene Powers, Communications Director, Wildlife Habitat Canada, 7 Hinton Avenue North, Suite 200, Ottawa, Ontario, K1Y 4P1. Telephone: (613) 722-2090, Fax: (613) 722-3318, E-mail: fsrp@whc.org, Website: http://stewardship.cppa.org (english) OR http://intendance.cppa.org (french). About Wildlife Habitat Canada. Wildlife Habitat Canada is a national non-profit organization dedicated to working with private citizens, governments, non-government organizations, and industry to conserve the great variety of wildlife habitats across Canada. Partnerships are a key element to our success because they represent a cooperative effort between groups who share an interest in, and responsibility for, the conservation of wildlife habitat. Without habitat, there is no wildlife -it's that simple.

\title{
$\triangle$ A G R Earth \& Environmental Engineering \& Environmental Services
}

\section{Cost of Battling Forest Fires Hits Record}

Record high temperatures have created record problems for Canada's forest firefighters, particularly in the West.

More money was spent putting out flames in Canada's forests in 1998 than has ever been spent before - and twice the normal amount of hectares succumbed to the fires.

In total, 4.6-million hectares of forest were destroyed by flame in 1998 . That isn't a record, but it's almost double the normal amount.

The increase in fires has largely been caused by the record heat experienced in Canada and around the world. It can also be attributed to the dry winter. Worst hit were Saskatchewan, Alberta, British Columbia, Northwest Territories and the Yukon.

\section{Canadian Woodlands "Forum"}

\section{Balsam Fir Sawfly Control is Possible with Virus}

High populations of the balsam fir sawfly are expected in Newfoundland and Cape Breton this coming summer. The Canadian Forest Service has found that a virus naturally occurring in the balsam fir sawfly may provide the best way to control this damaging insect. The artificial introduction of this indigenous, insectspecific, environmentally friendly virus could accelerate the natural collapse of the population. (A similar, naturally occurring virus, OpNPV, has been used operationally and successfully to control an outbreak of douglas fir tussock moth in BC.) The sawfly virus produced in the laboratory will be applied to the insects in the field to produce even more virus - a process known as field amplification. By this process, sufficient virus to treat large areas of infection can be produced economically. For further information contact Dr. Chris Lucarotti or Dr. Graham Thurston, Canadian Forest Service, Fredericton, (506) 452-3538, e-mail clucarotti@NRCan.gc.ca

\section{Canadian Woodlands "Forum"}

\author{
A CIF/IFC Corporate Sustaining Member
}

